NBER WORKING PAPER SERIES

LINKAGE OF GREENHOUSE GAS EMISSIONS TRADING SYSTEMS:

LEARNING FROM EXPERIENCE

\author{
Matthew Ranson \\ Robert Stavins \\ Working Paper 19824 \\ http://www.nber.org/papers/w19824
}

\author{
NATIONAL BUREAU OF ECONOMIC RESEARCH \\ 1050 Massachusetts Avenue \\ Cambridge, MA 02138 \\ January 2014
}

We are grateful for research assistance provided by John Agan, and helpful comments from Gilbert Metcalf and participants at a presentation of the paper at the Nineteenth Conference of the Parties of the United Nations Framework Convention on Climate Change in Warsaw, Poland. The authors are responsible for any remaining errors. The views expressed herein are those of the authors and do not necessarily reflect the views of the National Bureau of Economic Research. This paper was written with support from the Harvard Program on International Climate Agreements.

NBER working papers are circulated for discussion and comment purposes. They have not been peerreviewed or been subject to the review by the NBER Board of Directors that accompanies official NBER publications.

(C) 2014 by Matthew Ranson and Robert Stavins. All rights reserved. Short sections of text, not to exceed two paragraphs, may be quoted without explicit permission provided that full credit, including $\odot$ notice, is given to the source. 
Linkage of Greenhouse Gas Emissions Trading Systems: Learning from Experience

Matthew Ranson and Robert Stavins

NBER Working Paper No. 19824

January 2014

JEL No. Q28

\begin{abstract}
$\underline{\text { ABSTRACT }}$
The last ten years have seen the growth of linkages between many of the world's cap-and-trade systems for greenhouse gases (GHGs), both directly between systems, and indirectly via connections to credit systems such as the Clean Development Mechanism. If nations have tried to act in their own self-interest, this proliferation of linkages implies that for many nations, the expected benefits of linkage outweighed expected costs. In this paper, we draw on the past decade of experience with carbon markets to test a series of hypotheses about why systems have demonstrated this revealed preference for linking.

Linkage is a multi-faceted policy decision that can be used by political jurisdictions to achieve a variety of objectives, and we find evidence that many economic, political, and strategic factors - ranging from geographic proximity to integrity of emissions reductions - influence the decision to link. We also identify some potentially important effects of linkage, such as loss of control over domestic carbon policies, which do not appear to have deterred real-world decisions to link.

These findings have implications for the future role that decentralized linkages may play in international climate policy architecture. The Kyoto Protocol has entered what is probably its final commitment period, covering only a small fraction of global GHG emissions. Under the Durban Platform for Enhanced Action, negotiators may now gravitate toward a hybrid system, combining top-down elements for establishing targets with bottom-up elements of pledge-and-review tied to national policies and actions. The incentives for linking these national policies are likely to continue to produce direct connections among regional, national, and sub-national cap-and-trade systems. The growing network of decentralized, direct linkages among these systems may turn out to be a key part of a future hybrid climate policy architecture.
\end{abstract}

Matthew Ranson

Abt Associates

55 Wheeler Street

Cambridge, Massachusetts 02138

Matthew_Ranson@abtassoc.com

Robert Stavins

JFK School of Government

Harvard University

79 JFK Street

Cambridge, MA 02138

and NBER

robert_stavins@harvard.edu 


\title{
Linkage of Greenhouse Gas Emissions Trading Systems: Learning from Recent Experience
}

\author{
Matthew Ranson and Robert N. Stavins ${ }^{1}$
}

\section{INTRODUCTION}

Recent efforts to develop an effective global response to the risks of climate change have focused on two negotiation tracks. One - extending the Kyoto Protocol with a second commitment period-faced major challenges and resulted in limited participation or non-participation by a number of key industrialized ("Annex I") countries, including the United States, Canada, Russia, and Japan. The Protocol also failed to set emissions targets for developing ("non-Annex I") countries, thus excluding major greenhouse-gas (GHG) emitters such as China and India.

A second track - negotiations based on the roadmap known as the Durban Platform for Enhanced Action-may be eliminating the historical distinction in climate commitments between developed and developing countries. However, even with the impetus provided by the Durban Platform's stated commitment to negotiate a global climate treaty by 2015 , the history of international climate negotiations suggests that reaching a broad top-down international agreement to address climate change is likely to be extraordinarily difficult.

Given the challenges facing top-down international policy architectures, we evaluate a different possibility: a bottom-up policy architecture based on decentralized linkages between and among regional, national, and sub-national emissions trading systems (which may be part of a hybrid policy architecture combining bottom-up and top-down elements). Such an architecture-which is not mutually exclusive from the Durban Platform - would rely on bilateral and multilateral agreements in which nations would link their cap-and-trade systems together by accepting each other's allowances or credits. In principle, the links could create cost savings and market liquidity benefits for all connected systems, while achieving the same aggregate reductions in greenhouse-gas emissions. The linkage agreements could also provide mechanisms for countries to coordinate and harmonize their emissions caps, price controls, and other design features. By encouraging systems to work together through decentralized negotiations, linkage could, in principle, take the place of a centralized top-down climate agreement.

Of course, a key question about a climate policy architecture based on uncoordinated direct linkages is whether it could succeed in generating a sufficient quantity of greenhouse-gas emissions reductions at a reasonable cost (Heitzig, 2013). To address this question, we draw on the past decade of experience with carbon markets to test a series of hypotheses about why systems choose to link. We then assess the role that decentralized linkages may play in future international climate policy architecture.

\footnotetext{
${ }^{1}$ Ranson is an Associate in the Environment and Resources Division at Abt Associates Inc; Stavins is the Albert Pratt Professor of Business and Government at the John F. Kennedy School of Government, Harvard University, University Fellow of Resources for the Future, and Research Associate of the National Bureau of Economic Research. We are grateful for research assistance provided by John Agan, and helpful comments from Gilbert Metcalf and participants at a presentation of the paper at the Nineteenth Conference of the Parties of the United Nations Framework Convention on Climate Change in Warsaw, Poland. The authors are responsible for any remaining errors.
} 
Two conclusions emerge about motivations for linkage. First, there exists a significant revealed preference for linking emissions trading systems. The last ten years have seen the organic growth of linkages between many of the world's cap-and-trade systems, both directly between systems, and indirectly via connections to credit systems such as the Clean Development Mechanism (CDM). Under the assumption that nations act in their own self-interest, this proliferation of linkages implies that for many nations the expected benefits of linkage outweigh expected costs.

Second, the decision to develop a link between two systems depends on a variety of economic, political, and strategic factors. Although it may seem obvious that the primary goal of linkage is to achieve the same level of emissions reductions at a lower cost, it is important to recognize that linkage is a multi-faceted policy decision that can be used by political jurisdictions to achieve a variety of objectives. Consistent with this hypothesis, we find evidence that a set of factors-ranging from geographic proximity to integrity of emissions reductions - have influenced the decision to link. We also identify some effects of linkage, such as loss of control over domestic carbon policies, which do not appear to have had much impact on real-world decisions about linking.

These findings have implications for the likely role that decentralized linkages may play in future international climate policy architecture. Because a global offset market is not emerging, the possibility of achieving near-term cost savings through a system of indirect linkages seems unlikely. Furthermore, recent delinking by New Jersey and Australia demonstrates that linkages can easily be undone, implying that linkages may not survive changes in domestic political support. However, strong incentives for linking are likely to continue to produce direct connections among some regional, national, and subnational cap-and-trade systems.

The remainder of this paper is organized as follows. Section 2 describes existing and planned linkages between emissions trading systems for greenhouse gases. Section 3 presents theoretical and empirical evidence on whether and how a variety of economic, political, and strategic factors have influenced decisions about linkage between emissions trading systems. Section 4 evaluates the potential role of linkage in global climate policy architecture, and Section 5 concludes.

\section{BACKGROUND ON LINKAgES BETWEEN EMISSIONS TrAding SySTEMS}

Perhaps the most important lesson about linkage that has emerged over the past decade is that some regions, nations, and sub-national jurisdictions are eager to link their systems. As of September 2013, there were international, regional, national, or sub-national cap-and-trade systems operating or scheduled for launching in 36 countries. These include the EU Emissions Trading Scheme (EU ETS), the Regional Greenhouse Gas Initiative (RGGI), eight regional pilots in China, and emissions trading systems in Australia, California, Kazakhstan, New Zealand, Quebec, Switzerland, and Tokyo (World Bank, 2013b). Of these, most had established or proposed at least one international linkage with another capand-trade or credit system. These links fall into four general categories: one-way and two-way linkages between cap-and-trade systems; one-way linkages between cap-and-trade and credit systems; implicit linkages via national trading under Article 17 of the Kyoto Protocol; and various types of non-traditional linkage.

\subsection{LINKAGES BETWEEN CAP-AND-TRADE SYSTEMS}

Direct linkages between cap-and-trade systems can take several forms (Ranson and Stavins, 2013; Jaffe, Ranson, and Stavins, 2010). The simplest is a one-way linkage in which one cap-and-trade system allows its regulated entities to use allowances from another cap-and-trade system for the purposes of domestic compliance. If the price of allowances in the other system is lower than the price of allowances in the first system, then participants have an incentive to purchase allowances from the other 
system until prices are equalized in the two systems, resulting in net cost savings. If the price of allowances is higher in the second system, there is no incentive for international allowance purchases and so the linkage will have no effect.

Linkages may also be bilateral (or multilateral). These types of direct linkage allow participants in both (or all) systems to purchase allowances from each other for the purposes of domestic compliance. The free flow of allowances between systems results in an equalization of prices and leads to the costeffective allocation of abatement efforts across the linked systems.

The first panel in Table 1 lists all direct linkages between cap-and-trade systems in existence or announced, as of September 2013. There are currently two cases of planned one-way linkages. One is Australia's plan to accept EU ETS allowances beginning in July 2014. However, due to the election of a new government in September 2013, Australia's cap-and-trade system may be rescinded, resulting in the termination of this announced one-way linkage. The other example of one-way linkage is the language in RGGI's authorizing legislation that allows participants to use allowances from foreign cap-and-trade systems when and if RGGI allowance prices exceed specified trigger prices that started at \$10 in 2005 and increased by roughly 2 percent each year. Because RGGI prices have remained well below the trigger prices, this one-way linkage option has not been exercised. The proposed 2013 updates to the RGGI Model Rule end this conditional linkage.

Table 1 also lists several proposed bilateral linkages. The most prominent example is the agreement between California and Quebec to link their systems and hold joint permit auctions starting in 2014. Although Australia briefly had plans for a two-way linkage with the EU ETS starting in 2018, the new government's intention to cancel Australia's cap-and-trade system would presumably end this link as well (ClimateWire, 2013e).

Two multilateral linkages are presented in Table 1: the connections among the EU ETS nations, and the connections among the RGGI states. While these are not technically linkages between independent cap-and-trade systems, both involved countries or sub-national states negotiating an agreement to join their carbon markets together. Because of the similarities to linkage, Ellerman and Buchner (2007) argue that it is useful to view such systems as large sets of linked cap-and-trade programs.

\subsection{LINKAGES FROM CAP-AND-TRADE TO CREDIT SYSTEMS}

Cap-and-trade systems can also establish one-way linkages with emissions reduction credit (ERC) systems. In such a linkage, regulated entities in the cap-and-trade system are permitted to use offset credits from the ERC system for the purpose of domestic compliance. If prices are initially higher in the cap-and-trade system, then its participants will purchase credits until prices in the two systems converge (if the ERC system has a sufficient supply of offsets available). If prices are initially lower in the cap-and-trade system, then there will be no incentive to purchase credits and so the linkage will have no effect.

The second panel in Table 1 lists existing and proposed one-way linkages in which cap-and-trade systems have agreed to accept offsets from credit systems. By far the most economically important credit system, in terms of the volume of credits created, is the Kyoto Protocol's Clean Development Mechanism $(\mathrm{CDM})$. Under the CDM, firms and other entities in non-Annex I countries can be awarded certified emissions reduction (CER) credits for executing approved voluntary projects that reduce greenhouse-gas

emissions. Regulated emitters in Annex I countries can purchase these CERs for use in meeting their domestic emissions commitments. As Table 1 shows, several cap-and-trade systems, including the EU ETS, Switzerland, New Zealand, and Australia, have established such one-way linkages with the CDM. Of these, the EU ETS has been the dominant purchaser of CERs: As of 2011, 56 percent of issued CERs 
had been surrendered by EU ETS participants, and as much as 29 percent of remaining CERs were being held in European carbon registry accounts (Shishlov and Bellassen, 2012, p.16). Many other systems also accept CDM credits, including Switzerland, New Zealand, and Australia.

Other proposed offset programs also exist. For example, California has negotiated a Memorandum of Understanding with Acre, Brazil, and Chiapas, Mexico, to work together to develop a framework to allow the use of offsets from those states in California's cap-and-trade system under Assembly Bill 32 (AB 32).

\subsection{INDIRECT LinKageS VIA NATIONAL TRADING OF AAUS}

In addition to the system-level linkages shown in Table 1, many nations' cap-and-trade systems have informal, highly-indirect linkages that have occurred via national trading of Assigned Amount Units (AAUs). Under the Kyoto Protocol, each Annex I country was issued a quantity of AAUs equal to the GHG emissions target that it had accepted for the period from 2008 to 2012, measured in metric tons of $\mathrm{CO}_{2}$-equivalent. The Protocol stated that at the end of the compliance period, each country would be required to surrender enough AAUs to cover its actual emissions over the compliance period. If a country's emissions exceeded its AAUs, it was allowed to make up the difference by purchasing AAUs from another country under Article 17 of the Kyoto Protocol or by obtaining emissions credits under one of the project-based offset mechanisms-Joint Implementation and the Clean Development Mechanism (UNFCCC, 1998).

In principle, trading of AAUs between nations creates implicit linkages between their domestic carbon abatement policies. For example, consider a transfer of AAUs between two nations with cap-andtrade systems, both of which are committed to meeting their Kyoto Protocol commitments. By buying additional AAUs, the purchasing country would be able to relax the aggregate emissions cap in its domestic cap-and-trade system while still achieving its Kyoto target. Conversely, after the transaction, the selling country would need to tighten its emissions cap in order to meet its Kyoto commitment.

In practice, the market for AAUs has involved a very limited number of participants. This should not be a surprise (Hahn and Stavins, 1999). Table 2 summarizes information about all AAU transactions that had been tracked by the United Nations Environment Program as of early 2013 (UNEP Ris $\varnothing$ Centre, 2013). Most AAUs have been purchased by three groups of buyers: Japanese firms, Spain, and the World Bank. The other entities that have purchased AAUs are Austria, Belgium, Ireland, Japan, Luxembourg, the Netherlands, Portugal, and one U.S. firm. Virtually all transactions have occurred between 2008 and 2012. The table also shows that all AAU transactions have involved sales by central and eastern European countries, with the sole exception of a very small sale by New Zealand in 2010 .

\subsection{OTHER TYPES OF LINKAGE}

There have also been a few instances of partial and unconventional linkages, including some cases of what Burtraw et al. (2013) refer to as "linking by degrees". These types of linkages occur when systems take actions that fall short of a formal link but that nonetheless bring them closer into alignment. For example, Australia and California have signed a memorandum of understanding on sharing information and experience with cap-and-trade systems and with linking (ACER/CARB, 2013). Similarly, California and RGGI have engaged in information sharing and have borrowed some design elements from each other (Burtraw et al., 2013).

There is also the possibility, raised by Metcalf and Weisbach (2012), of indirect linkages among coordinated carbon tax systems. Carbon taxes are currently in place or planned in Australia, British Columbia, Denmark, Finland, Ireland, Japan, Norway, South Africa, Sweden, Switzerland, and the United 
Kingdom (World Bank, 2013b). Some of these taxes, particularly those in Europe, do appear to be intended to complement the carbon price established by the EU ETS (World Bank, 2013b). Such linkage, as well as linkage among heterogeneous national policies (Metcalf and Weisbach, 2012), is beyond the scope of this paper.

\section{Economic, Political, and Strategic Determinants of Linkage}

Overall, the number of linkages that have emerged over the last decade demonstrates that many jurisdictions have a revealed preference for linking their domestic cap-and-trade policies with those of other jurisdictions. If these regions, nations, and sub-national jurisdictions are acting in their own selfinterest, the existence of these linkages suggests that the expected economic and political benefits of linkage outweigh expected costs.

There are also a large set of examples of pairs of systems that, to-date, have demonstrated a preference for not linking with each other. For example, California and Quebec have not linked with the CDM; RGGI has not linked with California; and the EU ETS has not linked with any of the North American systems. Many of these unrealized linkages would be critical to the success of a bottom-up climate policy architecture. Why do systems choose to link or not to link?

The decision to link is potentially influenced by a variety of economic, political, and strategic factors. Although it may seem obvious that the primary goal of linkage is to achieve the same level of emissions reductions at lower cost, it is important to recognize that linking to another emissions trading system is a multi-faceted policy decision that can be used by political jurisdictions to achieve a variety of objectives (Flachsland et al., 2009). Therefore, we consider the possibility that a wide range of variables - ranging from geographic proximity to integrity of emissions reductions - influences the decision to link.

Because the number of proposed and existing linkages is too limited to permit a statistical analysis, we test our hypotheses using a qualitative approach. In the following sections, we describe a variety of variables that, on the basis of either theory or experience, could potentially influence decisions about linkage. For each variable, we review theoretical and empirical evidence on whether the variable actually has had a significant effect on the costs or benefits of linkage. We also discuss whether the observed pattern of international linkages to-date suggests that the variable has had an influence on decisions to develop links between emissions trading systems.

\subsection{GeOgRAPHIC PROXIMITY}

The single most significant predictor of two systems linking is geographic proximity (Table 1). The EU member states are linked with one another through the EU ETS; Norway, Lichtenstein, and Iceland joined the EU ETS; Quebec and California will link together in 2014, and have announced intentions to negotiate linkages with future offset programs in Acre, Brazil, and Chiapas, Mexico; northeastern U.S. states are linked through RGGI; and many aspects of New Zealand's cap-and-trade system were chosen with the intent of making them compatible with Australia's planned system.

Political economy studies of negotiated trade agreements provide some insight into this pattern, because in many ways, linkages resemble trade agreements. Both involve a commitment by one or both countries to accept allowances or goods from the other; both involve decentralized transactions that are carried out by pairs of participants in each country; and both can be advantageous because of the welfare gains to be had from voluntary exchange between partners with different comparative advantage. Of course, unlike traditional goods, which have intrinsic value, the value of a carbon allowance is determined 
solely by its scarcity due to an emissions cap. Even this has some parallel to the fact that countries are able to change the nominal value of their goods by manipulating their currencies.

One of the most robust findings from the international trade literature is the fact that trade agreements are most likely between pairs of nations that are located geographically close to each other. The standard explanation is provided by the "gravity model" of trade (Tinbergen, 1962), which predicts that the level of trade between two countries is a function of supply in both markets, demand in both markets, and the geographic distance between the two countries in nautical miles. The explanation for the significance of geography is associated with transportation costs and information about markets.

In the context of linkages between cap-and-trade systems, jurisdictions located near each other may have similar environmental goals and economic conditions and may have a history of mutually beneficial engagement on other issues. Linkages with neighbors may also be more palatable to domestic audiences. Anecdotal evidence from California, where some legislators have expressed concerns about linking to "far-flung jurisdictions" rather than immediate neighbors (ClimateWire, 2013a), is consistent with this political explanation.

\subsection{COST-EFFECTIVENESS}

In terms of economic considerations, the most important reason for linking is the increase in costeffectiveness that results from the reallocation of abatement effort between systems with different marginal abatement costs. The system with the higher marginal cost benefits from purchasing relatively inexpensive allowances from the other system, allowing it to achieve its emission reduction goals at a lower cost. Conversely, the system with the lower marginal cost benefits from selling its allowances at higher prices, resulting in an inflow of revenue.

If government decision makers act with the goal of maximizing national welfare, then these aggregate benefits would affect decisions about linkage. It is more likely, however, that political leaders support or oppose linkage policies based on anticipated effects on domestic constituents. For example, the cost savings available from linkage may play well to regulated businesses in the higher-cost system, and high allowance prices may be popular with constituents in the lower-cost system. Of course, linkage could also have negative political effects: For example, large international revenue transfers may be a political liability in the system that is making the payments.

The net welfare gains from linking could be substantial, as Carbone et al. (2009) find in a gametheoretic analysis. This is supported by recent empirical evidence. The best example may be the linkage between the EU ETS and the CDM, which has allowed regulated EU firms to purchase offsets from a variety of developing countries. Trotignon (2010) suggests that in the first two years of the Phase II (Kyoto) compliance period (that is, 2008-2009), EU ETS installations saved at least 280 million euros by purchasing CERs instead of making higher-cost domestic emissions reductions. Over the period from 2008 to 2011, the total savings may have exceeded $\$ 1.2$ billion (UNFCCC, 2012).

Despite the theoretical and empirical evidence that linkage results in cost savings, the empirical pattern of international linkages suggests that potential cost savings are often counterbalanced by negative factors associated with linkage. The linkage of the EU ETS with the CDM and proposed linkage of California with Acre and Chiapas demonstrate the readiness of cap-and-trade systems to link with ERC programs with lower marginal abatement costs. However, many potentially cost-saving bilateral linkages have not occurred, such as California-RGGI and EU-California. Furthermore, despite the primary role that the CDM has played in providing cost savings for European firms, the EU ETS has effectively delinked from the CDM for the post-2012 period. These patterns suggest that for high marginal cost systems, other concerns (for example, about the shared ambition of emissions targets or about the environmental integrity of offsets) may be more important than cost savings. 
Nevertheless, access to revenue streams from the sale of allowances and offsets appears to be an important consideration for low-cost countries that are considering linkage. To date, the revenue flows from linkage between emissions trading systems have been considerable. For example, between 2007 and 2011, the sale of CERs is estimated to have generated between $\$ 9.5$ and $\$ 13.5$ billion in revenues for CDM project owners, most of whom were located in developing countries (UNFCCC, 2012).

\subsection{DISTRIBUTIONAL IMPACTS}

Although the net social welfare gains from linkage are an important factor driving linkage, the distribution of welfare impacts across regulated entities is also likely to matter (Newell, Pizer, and Raimi, 2013). Not all regulated entities benefit from linkage, and the relative political power of winners and losers could have strong impacts on governmental support for linking with another system.

Consider a two-way linkage between two cap-and-trade systems. Generally speaking, in the system with the higher pre-linkage allowance price, firms with high abatement costs (allowance buyers) will benefit from linkage, and firms with low abatement costs (allowance sellers) will be hurt by linkage, since linking will lower allowance prices in the high-priced system. Similarly, in the system with the lower pre-linkage allowance price, firms with high abatement costs will be hurt by linkage, and firms with low abatement costs will benefit from linkage.

Figure 1 illustrates this for a firm in the system with the lower pre-linkage allowance price. In the figure, the heavy black curve shows the firm's marginal abatement cost of reducing $\mathrm{CO}_{2}$ emissions, and $\mathbf{Q}^{*}$ is the quantity of emissions that the firm would emit the absence of a cap-and-trade system. The figure assumes that allowances are freely distributed to participants in each system (i.e., not auctioned). Prior to linkage, the domestic allowance price is $\mathbf{P}_{\mathbf{N}}$, and the firm purchases $\mathbf{Q}_{\mathbf{N}}$ allowances and then abates an additional $\mathbf{Q}^{*}-\mathbf{Q}_{\mathbf{N}}$ tons of $\mathrm{CO}_{2}$. After linking, the competitive allowance price increases to $\mathbf{P}_{\mathbf{L}}$, and as a result, the firm decreases the quantity of allowances it purchases (and its emissions) to $\mathbf{Q}_{\mathbf{L}}$, and then makes up the difference by increasing its abatement to $\mathbf{Q}^{*}-\mathbf{Q}_{\mathbf{L}}$ tons of $\mathrm{CO}_{2}$. Because the firm sells more allowances at a higher market price, linkage increases its revenue an amount equal to the light shaded area in the graph. However, because it must also pay the higher price for the allowances that it does purchase, linkage increases its costs by an amount equal to the dark shaded area on the graph. If the change in revenue is greater than the change in cost (as shown in the figure), then the firm will be a net beneficiary from linkage. However, this need not be the case, and in practice, some firms will benefit, and some will be worse off.

\subsection{MARKet LiQUidity AND PriCe Stabilization}

In principle, by increasing and diversifying the number of buyers and sellers in a carbon market, linkage can provide the dual benefits of increasing liquidity and reducing price volatility (although price volatility will also be transmitted from one system to another). This "market-making" property of linkage is particularly important for small cap-and-trade systems with relatively few participants. Consistent with this hypothesis, almost all of the smallest independent cap-and-trade systems have taken steps to link with other systems. Norway created a one-way linkage with the EU ETS in 2005, and then joined the EU ETS in 2008; New Zealand's ETS and the Japanese voluntary ETS have established one-way links to the CDM; and Switzerland is in the process of negotiating a two-way link with the EU ETS.

Linkage does appear to have increased the liquidity of allowance markets in these small cap-andtrade systems, but its contribution to price stability has been mixed. Although linkage seems likely to have helped to minimize day-to-day fluctuations in prices, it also appears to have increased the exposure of small systems to systematic risk. For example, due to New Zealand's decision to allow the unrestricted 
use of Kyoto credits, New Zealand Unit (NZU) prices have largely tracked CDM prices, which are in turn dependent on EU ETS prices. As shown in Figure 2, the collapse of European Union Allowance (EUA) prices in 2011 and 2012 propagated through the indirect linkage and led to a similar decline in NZU prices. Although the global recession was surely felt in New Zealand, in the absence of the linkage, it is not clear that New Zealand's allowances would have declined in this way.

\subsection{DOMESTIC OPPOSITION TO CAP-AND-TRADE}

In order to link a domestic cap-and-trade system with another emissions trading system, a jurisdiction must, obviously, have its own system. It is beyond the scope of this paper to explain why some nations but not others have taken action on climate change, but it is clear that supportive domestic political leadership is an important predictor of the adoption of a cap-and-trade system - and thus, by extension, of the decision to link.

Consider two recent examples of elected politicians who have decided to eliminate their domestic cap-and-trade systems, thus effectively delinking from other emissions trading systems. First, in November 2011, Governor Chris Christie of New Jersey announced that his state would withdraw from RGGI (NJ.com, 2011). New Jersey's exit resulted in the retirement of 21 million short tons of $\mathrm{CO}_{2}$ allowances (relative to a total RGGI cap of 150 million short tons), then valued at less than the RGGI floor price of $\$ 1.89$ per ton. Governor Christie implemented the withdrawal through an executive order, thus avoiding the need for legislative action.

Second, in September 2013, the newly elected Australian government, led by Prime Minister Tony Abbott, announced that it would propose legislation to terminate Australia's plans to move to a capand-trade system in 2014 (ClimateWire, 2013e). If the legislation passes, this decision would end the previous government's negotiated deal for a one-way link with the EU ETS starting in 2014 and a twoway link starting in 2018.

Although the details of these two cases of delinking differ, they illustrate that the decision to establish a link is not permanent, and that regardless of its costs and benefits, linkage requires sustained domestic political support for market-based action on climate change.

\subsection{International Political Strategy}

Linkages are agreements between regional, national, or sub-national jurisdictions, and like other forms of international cooperation, they involve strategic political behavior. There is good evidence of at least three different specific strategies that have involved decisions about linking, and many others are possible.

First, some nations may see linkage as a way to build support for international climate action by demonstrating leadership, coordinating policies and abatement effort, and developing mutual trust. Documents published by the EU ETS support this. For example, the European Commission website states that: "Linking the EU ETS with other cap-and-trade systems offers several potential benefits, including reducing the cost of cutting emissions, increasing market liquidity, making the carbon price more stable, leveling the international playing field and supporting global cooperation on climate change" (European Commission, 2013a; emphasis added).

Second, nations may be coerced into linkage as a condition for receiving some other benefit. The eastern European member states are a prime example. Many of these countries would have preferred not to join the EU ETS, but were forced to participate in this multilateral linkage as a condition of EU 
membership (Ellerman and Buchner, 2007). For these countries, the expected "club benefits" of the EU ETS presumably outweighed the expected costs of accepting emissions targets and joining the EU ETS.

Finally, nations may use linkage as a "carrot" that is intended to encourage the development of emissions trading systems in other jurisdictions. Again, EU ETS policy provides an example. From 2008 to 2012, EU ETS rules permitted the use of CDM credits from any developing country. However, beginning in 2013, the EU ETS ceased accepting new offsets from CDM projects located outside of Least Developed Countries (LDCs). This strategic decision to delink effectively excludes China and India which together have produced 68 percent of CDM offsets to-date - from selling CERs to the European market.

EU ETS documents imply that this policy change is at least partially intended to encourage these important emitters to develop their own cap-and-trade systems as a condition of accessing buyers in the EU ETS carbon market. The European Commission (2011) states that "[w]hile initially the use of international credits was allowed for cost-effective compliance, this has been complemented with the objective of actively using the leverage the EU possesses as the by far most important source of demand for international credits." Similarly, European Commission (2013a) states that: "To reduce global greenhouse gas emissions most cost-effectively the international carbon market needs to be developed by creating a network of linked cap-and-trade systems. In this process, international crediting mechanisms can play a valuable but transitional role". The public documents even suggest that the ongoing effort to develop "New Market Mechanisms" is intended to be temporary: "New sectoral crediting mechanisms would be a stepping stone towards establishing cap-and-trade systems in these developing countries" (European Commission, 2012b).

\subsection{REDUCED INTEGRITY OF EMISSIONS REDUCTIONS}

Linkage often requires a cap-and-trade system to accept some uncertainty about the quality of the allowances or credits that it purchases from the linked system. This problem is particularly acute for links to credit systems, which suffer from the problem of imperfect additionality: the challenge of determining whether or not a claimed emissions reduction would have occurred anyway in the absence of the offset program. As the world's largest credit system, the CDM has come under particularly heavy criticism about the limited additionality of its offsets. At the extreme, early CDM offsets that were issued for destruction of hydrofluorocarbons may have actually had the perverse effect of creating incentives to build additional refrigerant-producing factories solely for the purpose of destroying their HFC-23 emissions (Carbon Trust, 2009). This specific problem had a clear effect on linkage: in April 2013, the EU ETS ceased accepting CDM offsets based on HFC-23 destruction.

Concerns about additionality also apply to the indirect linkages created by international trades in AAUs. Many of the eastern European countries involved in sales of AAUs were expected to have a surplus of allowances, leading to the criticism that the AAU market involves trades of "hot air." Although little data is available on AAU transaction prices, AAUs do appear to have traded at a substantial discount relative to more credible types of allowances (e.g., EU ETS permits), likely reflecting the belief that AAUs do not represent real emissions reductions (Aldrich and Koerner, 2012). It is worth noting, however, that despite this discount, the price of AAUs is not zero, and some transactions have involved prices of as much as five to ten euros per metric ton of $\mathrm{CO}_{2}$-equivalent (Aldrich and Koerner, 2012).

Finally, due to the complicated incentives created by cap-and-trade systems, even direct linkages with another cap-and-trade system can lead to problems with environmental integrity of emissions reductions (Jaffe, Ranson, and Stavins, 2010). The issue that is raised here is leakage: the possibility that as a result of establishing a link between two systems, profit-maximizing firms in the system that previously had the lower price would seek to move their emissions-generating economic activity outside 
of the regulated jurisdiction, in an effort to avoid paying the higher post-linkage equilibrium allowance price. This concern appears to have had some real-world relevance: Australia, for example, has expressed reluctance to link to sub-national systems due to concerns about leakage (Bushnell, 2013).

\subsection{DOMESTIC ABATEMENT INCENTIVES}

One of the primary effects of linkage is to reduce the price of allowances in the system that originally had a higher permit price. Although this reduction in costs is what generates the costeffectiveness benefits of linkage, there are several reasons why the lower carbon price may be undesirable. For example, some jurisdictions may use cap-and-trade as a way to establish domestic price incentives for long-term investments in low-carbon infrastructure or in technological innovation (Calel and Dechezlepretre, 2012). The lower post-linkage price will reduce these investment incentives, possibly resulting in dynamically inefficient emissions reductions. Similar issues may arise for cap-andtrade systems that are developed based on some notion of moral responsibility.

In practice, domestic abatement incentives appear to be an important consideration for the decision to link. For example, the RGGI model rule includes language that allows the use of international credits and allowances for compliance purposes if RGGI prices exceed a threshold trigger price. Although this language is usually interpreted as a cost-control measure, it also implies that the RGGI states preferred the costs of abatement to be borne by domestic firms, unless they exceeded the trigger price. If this were not the case, the legislation could simply have permitted the use of offsets (or at least allowances from other cap-and-trade systems) regardless of the RGGI price.

The widespread use of quantitative limits on the use of offsets from linked credit systems appears to be motivated - at least in part — by the desire to establish domestic abatement incentives. Table 3 illustrates that most systems place relatively strict limits on offset use. Except for New Zealand, which allows for unrestricted use of credits from Kyoto programs, no system allows more than 20 percent of emissions to be covered with offsets, and few allow more than 10 percent of emissions to be covered. Although this doubtless reflects the perception that offsets may not represent real and permanent emissions reductions, it is also motivated by the stated goal of many systems of achieving domestic emissions reductions. A good example is provided by the recent decision by the EU ETS to cease accepting new offsets from CDM projects located outside of Least Developed Countries (LDCs). This change in policy is due to Article 11a(4-5) of Directive 2003/87/EC, which was triggered automatically by the absence of a world climate agreement by the end of 2010. The decision effectively excludes China and India from selling CERs to the European market.

Although the European Commission (EC) is working to develop a set of "New Market Mechanisms" that would use sectoral crediting as a way to engage non-LDC developing countries, EC documents do not indicate much concern about the end of the linkage with the two countries that have been the major players in the CDM market. The EC website states with regard to the new restrictions on CDM credits: "The Commission does not share the view that the market would be disrupted by a (temporary) shortage of supply of international credits. The flexible nature of the EU ETS design would simply result in the allowance price incentivising more reductions in installations covered by the EU ETS and a reduced reliance on international credits for compliance purposes" (European Commission, 2011, p.8).

\subsection{LEGAL COMPATIBILITY}

Legal compatibility is an important consideration for the linkage of two systems. The legal frameworks that support most cap-and-trade systems are based on authorizing legislation that is later implemented with regulations issued by an executive agency. Thus, in order for a link to be possible, the 
legislature must have the authority to link to a foreign jurisdiction, and the executive agency must have received authority from the legislature to implement appropriate linking regulations.

Legal compatibility may be particularly important for sub-national systems that may not have authority to negotiate treaties with foreign nations. The empirical pattern of linkage supports this hypothesis. There are many cases of linkages between sub-national states and provinces: the RGGI states are linked together; California and Quebec plan to link in 2014; and California is in the process of negotiating offset protocols with the states of Acre, Brazil, and Chiapas, Mexico. However, we are not aware of any cases of a state or province establishing links with another nation or group of nations. As California Air Resources Board Chairwoman Mary Nichols has said, "for a state to link with a sovereign nation presents some legal challenges that would be difficult to work through" (ClimateWire, 2013c).

\subsection{Similarity OF EMISSIONS TARgETS AND PRICES}

It is conceivable that countries with very different emissions-reduction ambitions may find it difficult to negotiate a link (Burtraw et al., 2013). There are at least two reasons for this. First, differences of ambition may signal differences of opinion over which countries should pay for emissions reductions. Second, differences of ambition can lead to substantial differences in allowance prices. In this case, linkage can generate substantial revenue transfers that may be unpalatable to politicians and the general public.

In theory, of course, different ambitions need not be an important obstacle: Systems could simply implement an "allowance exchange ratio" when they link (Burtraw et al., 2013). For example, in a particular year, one system might allow its regulated entities to substitute 1.2 foreign allowances for one domestic allowance for the purposes of domestic compliance. But, in practice, differences in ambition and prices appear to be real barriers to linking. For example, California has cited the collapse of EU ETS allowance prices as a reason for not working to develop a link with the EU ETS (ClimateWire, 2013c). Similarly, Burtraw et al. (2013) argue that the absence of a link between RGGI and California is due in large part to the weakness of RGGI prices.

Several of the largest international linkages, including the EU ETS nations' multilateral link, the RGGI states' multilateral link, and the planned California-Quebec link, have been negotiated without knowing what prices would have been in any of the individual systems, had the linkage not occurred. These linkages might well have been more difficult politically to establish if each participating system had already had a carbon price in place.

\subsection{LosS OF CONTROL OVER CARbON MARKETS AND EMISSIONS TARgETS}

Establishing a link with another system can mean sacrificing some control over domestic carbon prices. In the case of a two-way linkage, this loss of control results from the fact that after the link, prices will be determined by the equilibrium of aggregate supply and demand for allowances in the two systems. Because demand for allowances is determined by the caps set by both jurisdictions, each faces the risk that the other system may choose a cap that could create negative economic effects for the other. In a one-way linkage, a similar phenomenon may occur, but the linkage can only decrease domestic allowance prices, not increase them.

In practice, within linkages most nations have been price takers. In Figure 3, we compile information about all existing or proposed decisions by any nation or sub-national state to establish a link 
with another nation or state (or group). ${ }^{2}$ For each unique decision, we calculate the ratio between the nation or state's domestic cap and the combined post-linkage cap in the joined system and present the distribution of these ratios. The vast majority of nations and states enter into linkages in which their domestic cap accounts for less than ten percent of the combined post-linkage cap, and in all but two cases, the ratio is less than 35 percent. The only exceptions are California's planned link with Quebec, in which California will account for 87 percent of the combined cap, and the EU ETS' planned link with Australia, in which the EU ETS would most likely have accounted for approximately 75 percent of the combined cap. ${ }^{3}$

Linkage also requires systems to relinquish some control over the ambition of their domestic emissions targets. Figure 4 summarizes the differences between proposed and actual Phase II emissions caps for each of the EU ETS member states, as a function of per capita GDP. ${ }^{4}$ The proposed caps were the starting point for the Phase II negotiations and thus include a variety of strategic considerations. A robust pattern emerges: Countries with lower GDP per capita tended to propose much higher caps than they eventually accepted. This pattern suggests that linkage may have led low-marginal-cost countries to agree to more ambitious domestic caps than they would have implemented on their own.

Not only does linkage require systems to give up some control over prices and emissions targets, it can also require them to harmonize some design features. For example, as part of the negotiations to establish a one-way linkage between Australia and the EU ETS, Australia agreed to lower the maximum allowable domestic use of Kyoto units from 50 percent of a regulated entity's compliance obligation to 12.5 percent of its obligation and to eliminate its planned price floor (Lancaster, 2012).

Despite the fact that linkage leads to loss of control over domestic carbon markets, many nations and sub-national states have chosen to establish links, suggesting that control is not a determinative factor in countries' decisions about linking, at least when other nations in the linkage agreement have similar objectives.

\section{BOTTOM-UP ARCHITECTURE BASED ON LINKAGES}

A key question about a possible bottom-up climate policy architecture based on direct linkages is whether it could succeed in generating a sufficient quantity of greenhouse-gas emissions reductions at a reasonable cost (Heitzig, 2013). The experience surveyed above suggests that although some regions, nations, and sub-national jurisdictions have exhibited a preference for linking their respective cap-andtrade systems, decisions about linking are affected by a wide variety of economic, political, and strategic considerations. It is not clear whether a broad coalition would be likely to emerge out of uncoordinated bilateral and multilateral linkages, and it is much less clear whether a bottom-up system would include ambitious targets (stringent caps).

\footnotetext{
${ }^{2}$ For the purposes of this analysis, we include each nation or state in a multilateral linkage as making a decision, but do not treat the system as a whole (for example, RGGI or the EU ETS) as a decision maker. However, for bilateral linkages, we treat both partners as decisions makers (including, for example, the EU ETS decision to negotiate a link with Australia).

${ }^{3}$ Given the Australian government's stated intention of decommissioning its cap-and-trade system, the linkage between the EU ETS and Australia is not likely to go forward.

${ }^{4}$ This analysis is in the spirit of Ellerman (2008), who analyzes the ratio of 2020 EU ETS auction rights to 2005 emissions as a function of per capita GDP by nation.
} 
This raises the question of what role decentralized linkages can play in international climate policy architecture. In Section 4.1, we evaluate the likely performance of a bottom-up, linkage-based architecture purely on its own merits. The findings are not particularly encouraging. But when we compare such a bottom-up architecture with top-down alternatives in Section 4.2, a more positive prognosis emerges.

\subsection{AN ARCHITECTURE OF LiNKAgES MAY ACHIEVE LiMited RESULTS}

A variety of commentators, including Heitzig (2013), have suggested that a bottom-up system of linkage could form the foundation for an effective global system to address climate change. For example, Jaffe, Ranson, and Stavins (2010) envisioned a two-part evolution of such a decentralized architecture. In the short-term, indirect linkages through a common credit system such as the CDM might provide costeffectiveness and market liquidity benefits. Each cap-and-trade system would use the international credit market as a cost-control mechanism that would place an upper bound on domestic abatement costs, thus enforcing some comparability in carbon prices across jurisdictions. These indirect links would not require detailed negotiations or international cooperation and thus would allow nations to implement domestic climate policies tailored to their specific economic and political circumstances. In the longer term, greater numbers of direct two-way and multilateral links might emerge. These links would require greater coordination of legislation, regulation, and institutions, while preserving national autonomy. The links would help to develop mutual trust among nations, thus possibly paving the way for meaningful emissions reductions commitments from a broad set of participants.

Based on our review of recent experience with system linkage, we identify three specific challenges to this vision.

\subsubsection{AN EFFECTIVE GLOBAL OFFSET MARKET IS NOT EMERGING}

First, due to some cap-and-trade systems' domestic emission-reduction objectives, concerns about additionality, and conflicting standards for approving offsets, a robust, effective, and meaningful global offset market does not appear to be emerging. From 2004 through 2012, the Clean Development Mechanism provided indirect links between many of the world's cap-and-trade systems. Although CDM prices were largely determined by demand from the EU ETS, several other systems-including New Zealand, Japan, and Switzerland - relied on the CDM as a source of credits. Limitations in many systems prevented full equalization of prices, but the central role played by the CDM helped facilitate some measure of global cost-effectiveness in emissions reductions.

Now, however, the CDM is losing its central role as a source of offsets for world carbon markets. Key factors for this decline include the EU ETS decision in 2013 to limit future CDM credits to projects from the least developed countries (LDCs), as well as the low price of EUAs. Additionally, new cap-andtrade systems in California and Quebec have established their own protocols for certifying offsets and have shown little interest in accepting CERs. Furthermore, the recent amendment authorizing the extension of the Kyoto Protocol allows the purchase of CERs only by parties to the Protocol's second commitment period (Prometheum Carbon, 2013), effectively eliminating any future possibility that U.S. or Canadian systems could accept CDM credits.

The dramatic decline in the role of the CDM is documented in Figure 5, which shows that the number of new projects grew more or less steadily from 2004 to 2012 and then fell to close to zero in 2013. Registration of new CDM projects has effectively ceased. Although there has been discussion of developing a new set of sectoral crediting programs ("New Market Mechanisms"), no project-based or sectoral credit system appears likely to take the place of the CDM in the short run. 


\subsubsection{LINKAGES ARE NOT PERMANENT}

A second challenge to an architecture based on linkages is the fact that despite being codified in legislation and regulations, linkages are not permanent. ${ }^{5}$ Although the general trend over the past decade has been one of increasing connections among GHG emissions trading systems, there have been several major exceptions. First, in 2011, Governor Chris Christie of New Jersey used an executive order to withdraw his state from RGGI. Second, starting in 2013, the EU ETS stopped accepting CDM credits from non-LDC countries, thus effectively delinking from offset markets in China and India. Finally, in September 2013, Prime Minister Tony Abbott of Australia announced that his government would propose legislation to terminate Australia's plans to move to a cap-and-trade system in 2014, thus ending the nation's plans for one-way and two-way links with the EU ETS in 2014 and 2018, respectively.

These three examples of delinking demonstrate that like any other international or domestic agreement, linkages can be terminated. The first and third examples were the result of domestic opposition to cap-and-trade policies, suggesting that a bottom-up architecture of linkages would have limited ability to incentivize nations to commit to emissions reductions targets that are opposed by domestic constituents. Contrasting with these examples is the case of the eastern EU nations, many of whom have accepted emissions targets under the EU ETS as a condition of broader EU membership (Ellerman and Buchner, 2007). However, the club benefits of EU membership are likely much greater than the benefits of linkage alone.

\subsubsection{DifFERENCES IN REGIONAL ECONOMIC PERFoRMANCE}

The third challenge to an architecture based on linkage is developing a consistent mechanism to overcome carbon market volatility caused by differences in regional economic performance. Linkage is easiest between systems with similar allowance prices, or at least similar abatement ambitions, conditional on their relative levels of economic development.

As of September 2013, allowance prices in the EU ETS had fallen to four euros per ton, allowance prices in California were close to the auction floor price of $\$ 10.71$ per ton, and RGGI allowance prices had just begun to show some modest signs of rising above the auction floor price of $\$ 1.93$. The low prices in some ways represent success: These cap-and-trade systems were all able to achieve their target emissions reductions at costs far lower than originally envisioned. But the primary cause of these lower prices is the continuing aftermath of the Great Recession, and the sensitivity of prices to macroeconomic conditions may complicate future efforts to link.

\subsection{An Architecture Of Direct Linkages May Perform Better Than The Alternatives}

In principle, a top-down negotiated agreement among the nations of the world could produce a first-best solution to the problem of climate change. Although marginal abatement costs, baseline greenhouse-gas emissions, and vulnerability to climate change all differ across nations, the logic of Coase (1960) suggests that there exists some distribution of abatement responsibilities and side payments that could reduce global emissions to an appropriate level while leaving each nation at least as well off as it would have been in the absence of global action. The problem, of course, is that each nation would not be better off relative to its free riding on the international actions of others. The geopolitical reality suggests that the hurdles to negotiating a successful top-down agreement are large, as shown by two recent efforts to negotiate a global agreement.

\footnotetext{
${ }^{5}$ The potential economic consequences of delinking are beyond the scope of this paper. For an insightful discussion, see: Pizer and Yates (2013).
} 
Under the 1997 Kyoto Protocol, signatories from industrialized (Annex I) countries agreed to take on greenhouse-gas emissions targets for a first commitment period running from 2008 to 2012. Although the agreement was hailed as a victory by climate advocates and has been recently been amended to include a second commitment period, it has serious limitations. Due to Canada's withdrawal from the treaty, the decisions by Japan and Russia not to take on emissions targets for the second commitment period, and the non-participation of the United States, the Kyoto Protocol currently sets emissions restrictions for a very limited subset of industrialized nations, covering less than 15 percent of global GHG emissions in its newly negotiated second commitment period. Nearly all of the countries that have accepted targets under this second commitment period belong to the European Union - and thus have already agreed to similar emissions targets as part of their participation in the EU ETS. Although the Protocol constituted a major milestone in international climate negotiations, it is simply not on track to produce meaningful reductions in global GHG emissions.

The Durban Platform for Enhanced Action, negotiated during the 2011 Conference of the Parties in Durban, South Africa, may have broken new ground in the climate negotiations by stepping away from the Berlin Mandate of 1995, which established the dichotomous distinction of countries with (Annex I) and without emissions targets. It thereby opened up the possibility that all of the world's largest emitters of greenhouse gases - including the large emerging economies - could take on quantitative emissions targets (Aldy and Stavins, 2012). But, despite this potential step forward, the Durban Platform only establishes a new negotiation process that has the goal of reaching an agreement by 2015 to bring all nations under the same legal regime by 2020. As an agreement to reach agreement, it has limited significance unless its promise is realized. It is possible that the negotiation process may succeed, but the history of climate negotiations suggests that reaching a broad agreement on a top-down, centralized climate policy architecture will be extraordinarily challenging.

Given the drawbacks of the Kyoto Protocol and the difficulty of establishing a new global agreement under the Durban Platform, the near-term and even medium-term prospects for practical implementation of a top-down architecture appear modest at best. So, although a top-down architecture might be a first-best approach if it could be implemented, it does not compare favorably when assessed via a criterion of real-world feasibility.

In contrast, on the basis of feasibility, a bottom-up system of linkages, possibly under the auspices of the Durban Platform, appears more promising, at least in the short term. Nations have strong revealed preferences for linking, and the incentives underlying those preferences are likely to continue to produce additional direct connections among regional, national, and sub-national cap-and-trade systems. Although a bottom-up system of linkage is an imperfect solution that may not be capable of producing the same quantity of emissions reductions as a top-down negotiated agreement, a bottom-up linked system has the crucial merit of being feasible.

\section{CONCLUSION}

Developing an effective international policy architecture to address climate change has proven to be exceptionally challenging. The Kyoto Protocol has entered what is probably its final commitment period, and now covers only a small fraction of global GHG emissions.

Under the Durban Platform for Enhanced Action, negotiators may now gravitate toward a hybrid system. This would combine top-down elements for establishing targets or at least procedures for assessing targets with bottom-up elements of pledge-and-review tied closely to individual national policies and actions. 
Based on recent experience, the incentives for linking such national policies are likely to continue to produce direct connections among regional, national, and sub-national cap-and-trade systems. The growing network of decentralized, direct linkages among these systems may turn out to be a key part of a future hybrid climate policy architecture. 
Table 1: Linkages Between Emissions Trading Systems

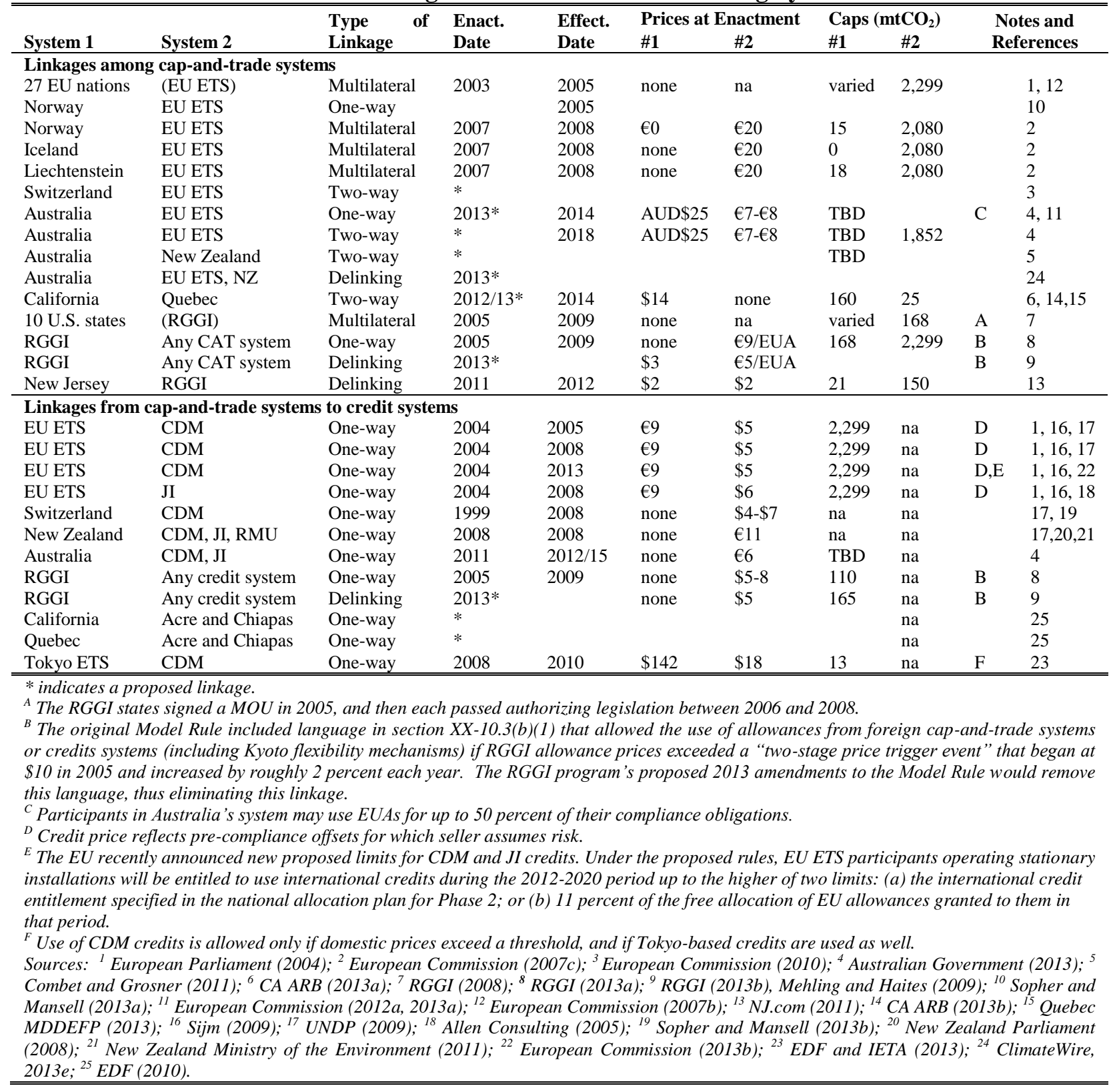


Table 2: Registered AAU Transactions

\begin{tabular}{|c|c|c|c|c|c|c|c|c|c|c|}
\hline \multirow[t]{2}{*}{ Buyer } & \multicolumn{10}{|l|}{ Seller } \\
\hline & Bulgaria & $\begin{array}{l}\text { Czech } \\
\text { Republic }\end{array}$ & Estonia & Hungary & Latvia & Lithuania & $\begin{array}{l}\text { New } \\
\text { Zealand }\end{array}$ & Poland & Slovakia & Ukraine \\
\hline & \multicolumn{10}{|c|}{ Years with Transactions } \\
\hline Austria & 2012 & 2009 & 2010,2012 & & 2009 & & & & & \\
\hline Belgium & & & & 2008 & & & & & & \\
\hline Ireland & & & & & & & & 2010 & & \\
\hline Japan (nation) & & 2012 & & 2010 & & & & & & \\
\hline Japan (firms) & & 2009-11 & 2010-12 & 2009 & 2009 & 2011 & 2010 & 2010 & 2002,2010 & 2009 \\
\hline Luxembourg & & & 2010 & & & 2011 & & & & \\
\hline Netherlands & & & & & 2009 & & & & & \\
\hline Portugal & & & & & 2009 & & & & & \\
\hline Spain & & 2009 & 2010,2011 & 2008 & 2009 & 2011 & & 2009,2012 & 2012 & 2009 \\
\hline US (private) & & & & & & & & & 2009 & \\
\hline \multirow[t]{2}{*}{ World Bank } & & 2010,2011 & & & & & & 2009,2012 & & \\
\hline & \multicolumn{10}{|c|}{ Cumulative AAU Sales Volume (MtCO2) } \\
\hline Austria & 6 & 3.5 & 4.4 & & 3.5 & & & & & \\
\hline Belgium & & & & 2 & & & & & & \\
\hline Ireland & & & & & & & & 2.5 & & \\
\hline Japan (nation) & & 12.5 & & 2 & & & & & & \\
\hline Japan (firms) & & 77 & 40.35 & 3 & 1.5 & a & 0.05 & 10.83 & 0.35 & 44 \\
\hline Luxembourg & & & 5 & & & a & & & & \\
\hline Netherlands & & & & & 3 & & & & & \\
\hline Portugal & & & & & 4 & & & & & \\
\hline Spain & & 5 & 12.5 & 6.6 & 5 & a & & $102.5^{\mathrm{b}}$ & 27 & 3 \\
\hline US (private) & & & & & & & & & 15 & \\
\hline World Bank & & 4.6 & & & & & & $60^{\mathrm{b}}$ & & \\
\hline
\end{tabular}


Table 3: Limits on the Use of Offset Credits

\begin{tabular}{llll}
\hline \hline System & Period & $\begin{array}{l}\text { Limit as \% } \\
\text { of Cap }\end{array}$ & Notes \\
\hline \hline EU ETS & $2013-2020$ & varies & (a) \\
EU ETS: Austria & $2008-2012$ & 10 & \\
EU ETS: Belgium & $2008-2012$ & 8.4 & \\
EU ETS: Czech Republic & $2008-2012$ & 10 & \\
EU ETS: Estonia & $2008-2012$ & 0 & \\
EU ETS: Finland & $2008-2012$ & 10 & \\
EU ETS: France & $2008-2012$ & 13.5 & \\
EU ETS: Hungary & $2008-2012$ & 10 & \\
EU ETS: Germany & $2008-2012$ & 12 & \\
EU ETS: Greece & $2008-2012$ & 9 & \\
EU ETS: Ireland & $2008-2012$ & 10 & \\
EU ETS: Italy & $2008-2012$ & 14.99 & \\
EU ETS: Latvia & $2008-2012$ & 10 & \\
EU ETS: Lithuania & $2008-2012$ & 20 & \\
EU ETS: Luxembourg & $2008-2012$ & 10 & \\
EU ETS: Netherlands & $2008-2012$ & 10 & \\
EU ETS: Poland & $2008-2012$ & 10 & \\
EU ETS: Slovakia & $2008-2012$ & 7 & \\
EU ETS: Slovenia & $2008-2012$ & 15.76 & \\
EU ETS: Spain & $2008-2012$ & 20 & \\
EU ETS: Sweden & $2008-2012$ & 10 & \\
EU ETS: United Kingdom & $2008-2012$ & 8 & \\
Swiss ETS & $2008-$ & 8 & \\
New Zealand ETS & $2008-$ & unlimited & \\
Australia's Clean Energy Act & $2012-$ & 12.5 & (b) \\
RGGI & $2009-$ & 3.3 & (c) \\
California's CAT system & $2013-$ & 8 or 0 & (d) \\
Quebec's CAT system & $2013-$ & 8 or 0 & (d) \\
\hline \hline
\end{tabular}

Notes: (a) The EU recently announced new proposed limits for CDM and JI credits. Under the proposed rules, EU ETS participants operating stationary installations will be entitled to use international credits during the 2012-2020 period up to the higher of two limits: (i) the international credit entitlement specified in the national allocation plan for Phase 2; or (ii) 11 percent of the free allocation of $E U$ allowances granted to them in that period. (b) From 2012 to 2015, the government may impose a fee of AUD $\$ 15$ to AUD $\$ 17$ per credit. The 12.5 percent limit applies to Kyoto credits (ERUs and CERs). (c) $R G G I$ 's limit rises to 5 percent if allowance prices exceed \$7, and to 10 percent if allowance prices exceed approximately $\$ 10$. (d) Neither California nor Quebec recognize offsets from UNFCCC flexibility mechanisms such as the CDM, although California has recently completed an MOU with the goal of eventually allowing deforestation credits from the states of Acre, Brazil, and Chiapas, Mexico.

Sources: See text above, and European Commission (2007c; 2013b) 
Figure 1: Effects of Linking on an Individual Regulated Firm

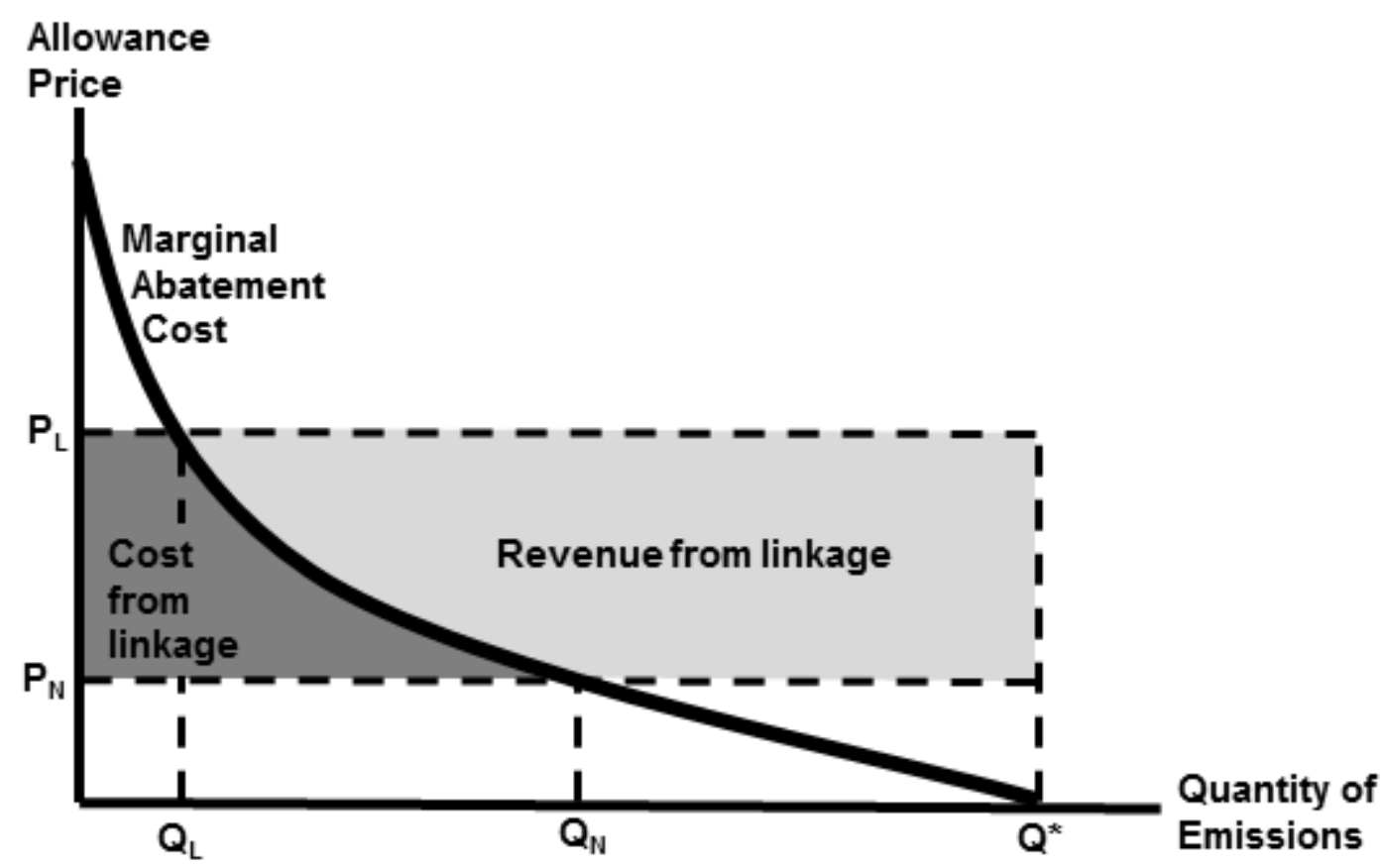

Note: The figure shows how linkage affects a regulated firm in the cap-and-trade system with lower initial compliance costs. The figure shows three different equilibria. $\mathbf{Q}^{*}$ is the quantity of emissions that the firm would emit the absence of a cap-and-trade system. $\mathbf{P}_{\mathbf{N}}$ is the domestic allowance price and $\mathbf{Q}_{\mathbf{N}}$ is the quantity of allowances that the firm purchases, before linkage occurs. $\mathbf{P}_{\mathbf{L}}$ is the combined allowance price and $\mathbf{Q}_{\mathbf{L}}$ is the quantity of allowances that the firm purchases, after linkage occurs. The figure assumes that 100 percent of allowances are freely distributed to participants in both systems (i.e., not auctioned). 
Figure 2: Spot Prices for NZUs, CERs, and EUAs

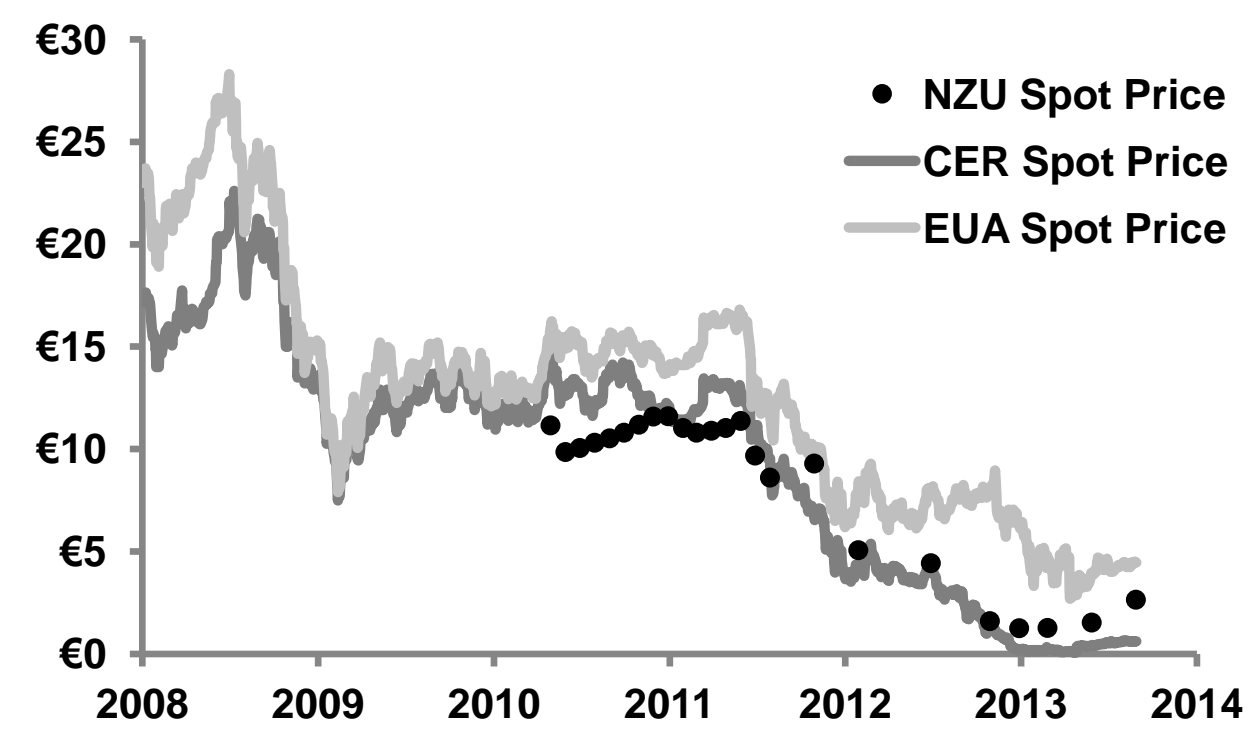

Note: All prices are shown in nominal euros. Sources: SendeCO2 (2013); Carbon CommTrade (2013). 


\section{Figure 3: Histogram of Ratio of Emissions Caps between Linked Systems}

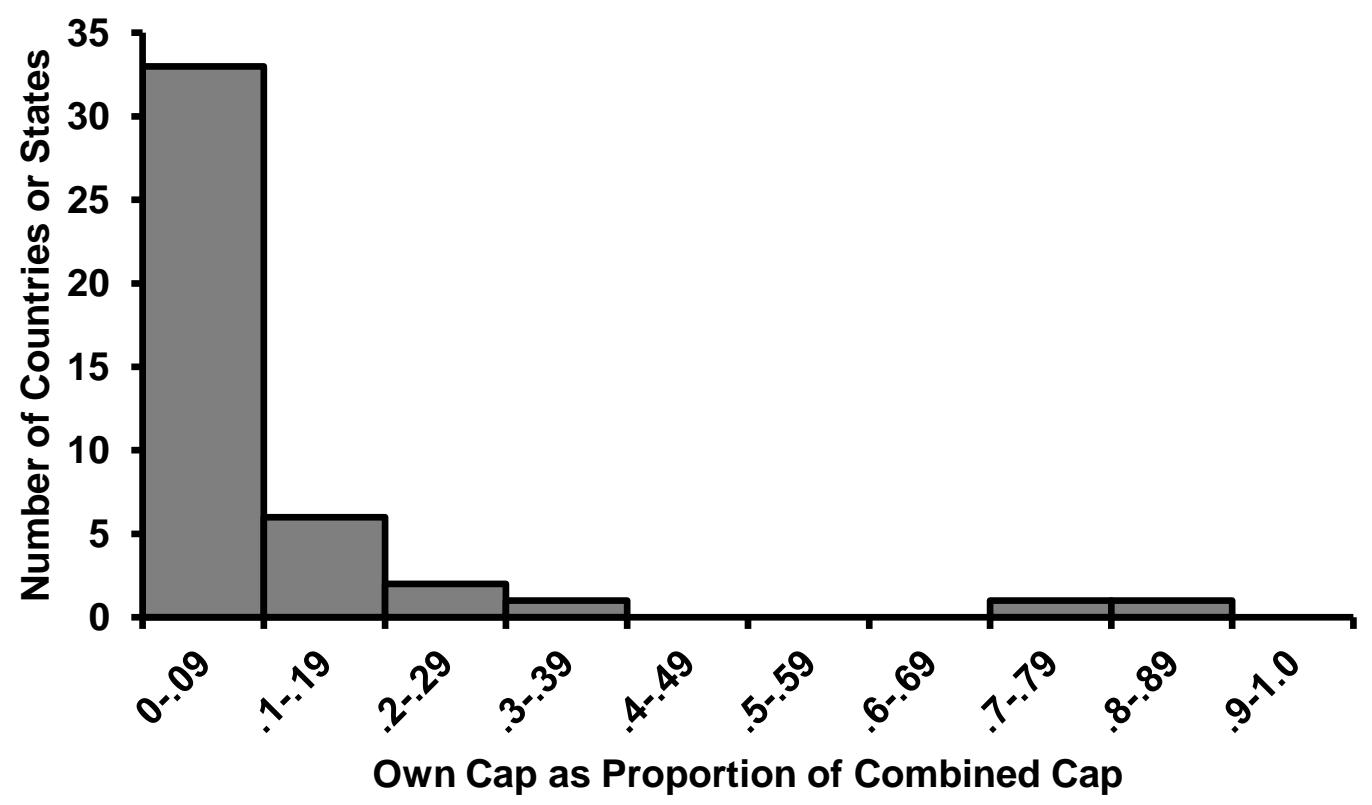

Note: Each observation in the histogram represents the existing or proposed decision by a nation or state to establish a linkage. For bilateral and multilateral linkages, each partner is included as a separate observation. The outcome variable is the ratio between the nation or state's domestic cap and the combined post-linkage cap in the joined system. Sources: see Table 1. 
Figure 4: Proposed and Final Phase II EU ETS Emissions Caps versus GDP per Capita

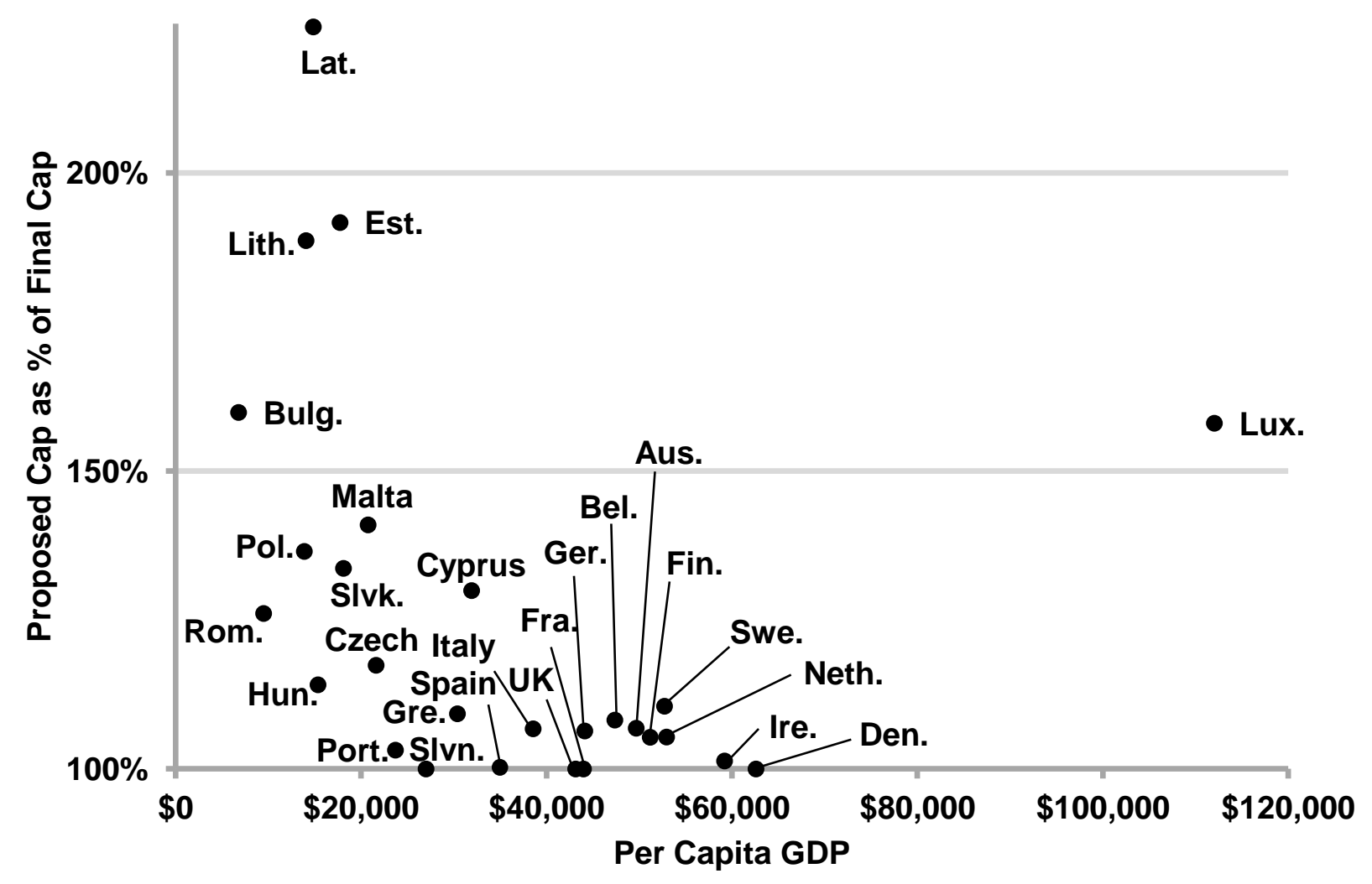

Note: Per capita national GDP is based on economic data from 2008; the dollar values are presented in 2013 USD. Source: European Commission (2007b); World Bank (2013a). 
Figure 5: Number of New CDM Projects Beginning Validation, by Month

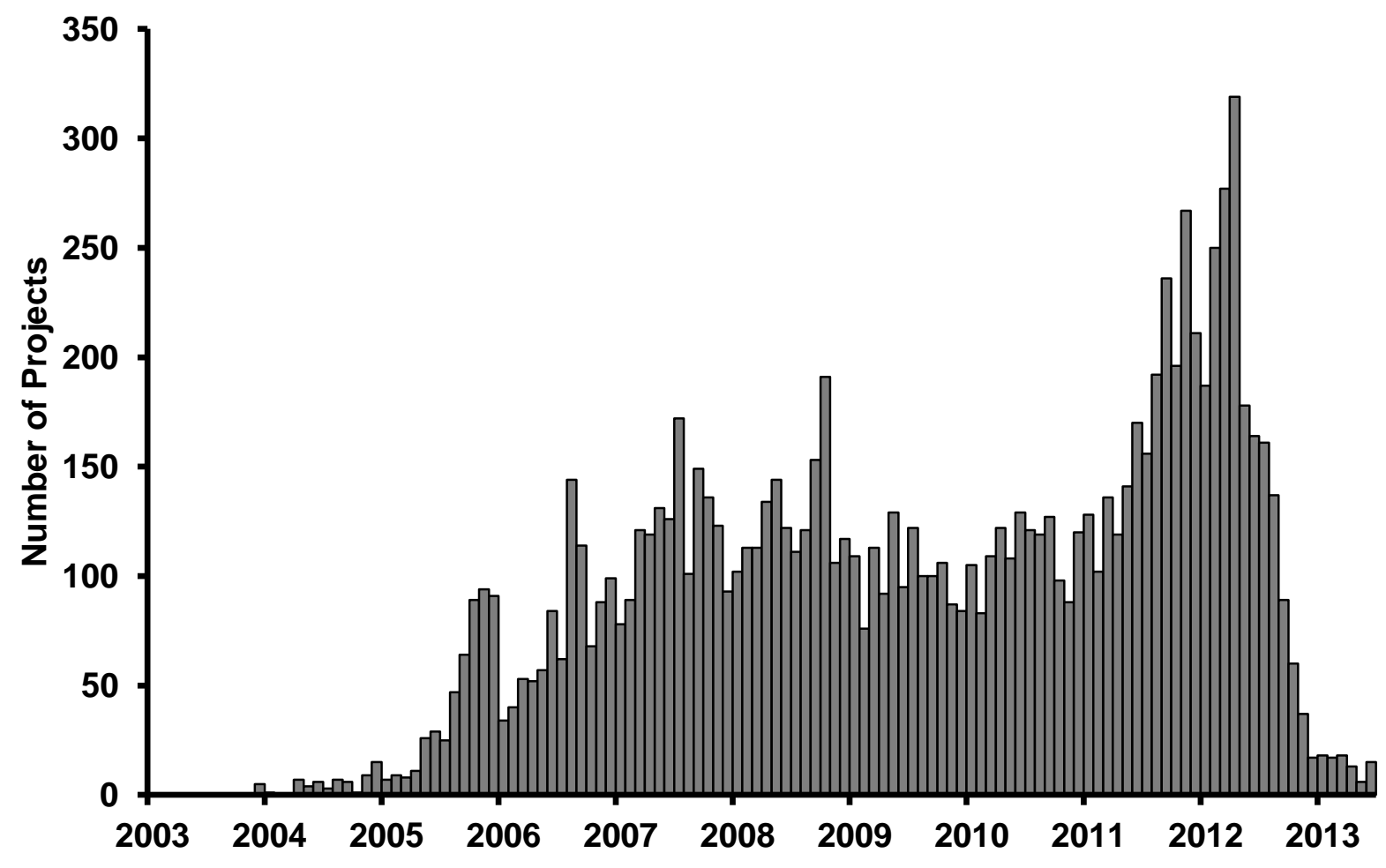

Note: The number of new CDM projects beginning validation, by month. Each project is assigned to a month based on the date it began the public comment phase. The data cover December of 2003 through June of 2013. Source: UNEP Risф Centre (2013). 


\section{REFERENCES}

Aldrich, Elizabeth Lokey, and Cassandra L. Koerner. 2012. "Unveiling Assigned Amount Unit (AAU) Trades: Current Market Impacts and Prospects for the Future." Atmosphere 2012 (3): 229-245. doi:10.3390/atmos3010229.

Aldy, Joseph, and Robert N. Stavins. 2012. "Climate Negotiations Open a Window: Key Implications of the Durban Platform for Enhanced Action.” Harvard Project on Climate Agreements. http://belfercenter.hks.harvard.edu/publication/22319.

Allen Consulting Group. 2005. "Report to New Zealand Treasury: The Cost of Tradeable Emissions Units Under the Kyoto Protocol." www.treasury.govt.nz/publications/informationreleases/carbonprice/kp-acg-jun05.pdf. Accessed 84-2013

Australian Government. 2013. "Starting Emissions Trading on 1 July 2014: Policy Summary." www.climatechange.gov.au/sites/climatechange/files/files/reducing-carbon/carbon-pricingpolicy/cef-policy-summary-moving-ets.PDF.

Australian Government Clean Energy Regulator, and California Air Resources Board (ACER/CARB). 2013. "Memorandum of Understanding Between the Clean Energy Regulatory and the California Air Resources Board." CER/ARB MOU Reference No. 1, July 30, 2013. www.arb.ca.gov/newsrel/2013/mou_cer_arb_073013.pdf.

Burtraw, Dallas, Karen L. Palmer, Clayton Munnings, Paige Weber, and Matthew Woerman. 2013. "Linking by Degrees: Incremental Alignment of Cap-and-Trade Markets." RFF Discussion Paper 13-04. www.rff.org/Publications/Pages/PublicationDetails.aspx?PublicationID=22167.

Bushnell, James. 2013. “A Ton Is Never Really a Ton.” Blog post, February 11, 2013. Energy Economics Exchange. http://energyathaas.wordpress.com/2013/02/11/a-ton-is-never-really-a-ton-2.

Calel, Raphael, and Antoine Dechezlepretre. 2012. "Environmental Policy and Directed Technological Change: Evidence from the European Carbon Market." Centre for Climate Change Economics and Policy, Working Paper 87. http://personal.lse.ac.uk/calel/Calel\%20and\%20Dechezlepretre\%20(2012).pdf.

California Air Resources Board. 2013a. "Air Resources Board sets date for linking cap-and-trade program with Québec.” www.arb.ca.gov/newsrel/newsrelease.php?id=430.

California Air Resources Board (CA ARB). 2013b. "Quarterly Auction 2, February 2013," Summary Results Report (June 5, 2013 Update). www.arb.ca.gov/cc/capandtrade/auction/february 2013/updated feb results.pdf.

Carbon CommTrade. 2013. "Price History: Spot NZUs." https://www.commtrade.co.nz. Accessed Sept. 12, 2013.

Carbon Trust. 2009. "Global Carbon Mechanisms: Emerging lessons and implications.” www.carbontrust.com/resources/reports/advice/global-carbon-mechanisms.

Carbone, Jared C., Carsten Helm, and Thomas F. Rutherford. 2009. "The case for international emission trade in the absence of cooperative climate policy." Journal of Environmental Economics and Management 58(3): 266-280. doi: 10.1016/j.jeem.2009.01.001 
ClimateWire. 2013a. "Legislature concerned about cap-and-trade links with other states, provinces." March 5, 2013. www.eenews.net/climatewire/2013/03/05/stories/1059977279.

ClimateWire. 2013b. "South Korea set to begin carbon trading in 2015.” March 6, 2013. www.eenews.net/climatewire/2013/03/06/stories/1059977331.

ClimateWire. 2013c. "E.U. market troubles will prevent emissions trade linkage - Calif. air chief." April 19, 2013. www.eenews.net/climatewire/2013/04/19/stories/1059979761.

ClimateWire. 2013d. "Nation learns lessons from E.U. while drafting its own emissions trading legislation.” April 19, 2013. www.eenews.net/climatewire/2013/04/19/stories/1059979736.

ClimateWire. 2013e. "New Australian government dismantling climate policies." September 12, 2013. http://www.eenews.net/climatewire/2013/09/12/stories/1059987111.

Coase, Ronald. 1960. "The Problem of Social Cost.” Journal of Law and Economics 3: 1-44. www.jstor.org/stable/724810.

Combet, Greg, and Tim Groser. 2011. "Joint Media Release: Australia and New Zealand Advance Linking of Their Emissions Trading Schemes." www.climatechange.gov.au/sites/climatechange/files/media/March\%202013/MR20111205B.pdf.

Ellerman, A. Denny, and Barbara Buchner. 2007. "The European Union Emissions Trading Scheme: Origins, Allocation, and Early Results." Review of Environmental Economics and Policy 1(1): 6687. doi: $10.1093 / \mathrm{reep} / \mathrm{rem} 003$

Ellerman, A. Denny. 2008. "The EU Emission Trading Scheme: A Prototype Global System?" Discussion Paper 08-02, Harvard Project on Climate Agreements. http://belfercenter.ksg.harvard.edu/publication/18488.

Environmental Defense Fund (EDF). 2010. “Tropical Forests Protection Pact Hailed for Protecting Climate." www.edf.org/news/tropical-forests-protection-pact-hailed-protecting-climate.

Environmental Defense Fund (EDF) and International Emissions Trading Association (IETA). 2013. "Tokyo: The World's Carbon Markets: A Case Study Guide to Emissions Trading." www.ieta.org/assets/Reports/EmissionsTradingAroundTheWorld/edf_ieta_tokyo_case_study_septe mber 2013.pdf.

European Commission. 2007a. "Emissions Trading: Commission Adopts Decisions on Amendments to Five National Allocation Plans for 2008-2012.” July 13, 2007: IP/07/1094. http://europa.eu/rapid/press-release_IP-07-1094_en.htm.

European Commission. 2007b. "Emissions trading: EU-wide cap for 2008-2012 set at 2.08 billion allowances after assessment of national plans for Bulgaria." October 26, 2007: IP/07/1614. http://europa.eu/rapid/press-release_IP-07-1614_en.htm.

European Commission. 2007c. "Emissions trading: Commission announces linkage EU ETS with Norway, Iceland and Liechtenstein." October 26, 2007: IP/07/1617. http://europa.eu/rapid/pressrelease IP-07-1617 en.htm.

European Commission. 2010. "Opening negotiations with Switzerland on linking Emissions Trading Systems.” November 5, 2010: http://ec.europa.eu/clima/news/articles/news_2010110501_en.htm. 
European Commission. 2011. "Questions and answers on use of international credits in the third trading phase of the EU ETS.” http://ec.europa.eu/clima/policies/ets/linking/docs/q_a_20111114_en.pdf.

European Commission. 2012a. "Press Release: Australia and European Commission agree on pathway towards fully linking Emissions Trading systems.” August 28, 2012. http://europa.eu/rapid/pressrelease_IP-12-916_en.htm?locale=en\#PR_metaPressRelease_bottom.

European Commission. 2012b. "Linking the EU ETS to Other Emissions Trading Systems and Use of International Credits.” http://ec.europa.eu/clima/policies/ets/linking/index_en.htm. Accessed Oct 16, 2012.

European Commission. 2013a. "International Carbon Market." Available at http://ec.europa.eu/clima/policies/ets/linking/index_en.htm. Accessed 9/15/2013.

European Commission. 2013b. "Climate Change Committee approves proposed Regulation on international credit entitlements for 2013-2020.” July 10, 2013. http://ec.europa.eu/clima/news/articles/news 2013071002 en.htm.

European Parliament. 2004. "Directive 2004/101/EC of the European Parliament and of the Council of 27 October 2004, amending Directive 2003/87/EC establishing a scheme for greenhouse gas emission allowance trading within the Community, in respect of the Kyoto Protocol's project mechanisms." Official Journal of the European Union L 338/18. http://eurlex.europa.eu/LexUriServ/LexUriServ.do?uri=CELEX:32004L0101:en:NOT.

Flachsland, Christian, Robert Marschinski, and Ottmar Edenhofer. 2009. "To link or not to link: benefits and disadvantages of linking cap-and-trade systems." Climate Policy 9 (4): 358-372. doi: 10.3763/cpol.2009.0626

Hahn, Robert W., and Robert N. Stavins. 1999. "What Has the Kyoto Protocol Wrought? The Real Architecture of International Tradable Permit Markets.” American Enterprise Institute. www.hks.harvard.edu/fs/rstavins/Papers/What_Has_Kyoto_Wrought.pdf.

Heitzig, Jobst. 2013. "Bottom Up Strategic Linking of Carbon Markets: Which Climate Coalitions Would Farsighted Players Form?" Nota di Lavoro 48.2013. www.feem.it/userfiles/attach/20135281552134NDL2013-048.pdf.

Jaffe, Judson, Matthew Ranson, and Robert N. Stavins. 2010. "Linking Tradable Permit Systems: A Key Element of Emerging International Climate Policy Architecture.” Ecology Law Quarterly, 36 (2010): 789-808. www.boalt.org/elq/documents/elq36-4-01-jaffe-2009-1209.pdf.

Kruppa, Marton. 2011. "Slovakia Eyes AAU Sales to Spain: PointCarbon,” Reuters. www.reuters.com/article/2011/12/21/us-carbon-slovakia-aau-idUSTRE7BK17V20111221.

Lancaster, Robin. 2012. "Editorial.” Carbon Trading 1(8): 1. www.carbon-tradingmagazine.com/wpcontent/uploads/2012/09/Carbon-Trading-October-20121.pdf .

Mehling, Michael, and Erik Haites. 2009. "Mechanisms for Linking Emissions Trading Schemes." Climate Policy 9 (2): 169-184. doi: 10.3763/cpol.2008.0524.

Metcalf, Gilbert, and David Weisbach. 2012. "Linking Policies When Tastes Differ: Global Climate Policy in a Heterogeneous World."Review of Environmental Economics and Policy 6 (1): 110-128. doi: $10.1093 / \mathrm{reep} / \mathrm{rer} 021$. 
NJ.com. 2011. "Gov. Christie announces N.J. pulling out of regional environmental initiative.” May 28, 2011. www.nj.com/politics/index.ssf/2011/05/gov_christie_to_announce_nj_pu.html.

New Zealand Ministry of the Environment. 2011. "Emissions Trading Scheme Review 2011: Issues statement and call for written submission." Emissions Trading Scheme Review Panel. Wellington: Ministry for the Environment. www.climatechange.govt.nz/emissions-trading-scheme/ets-review2011/issues-statement.pdf.

New Zealand Parliament. 2008. "Climate Change Response (Emissions Trading) Amendment Act 2008." Public Act 2008 No 85. www.legislation.govt.nz/act/public/2008/0085/latest/DLM1130932.html.

Newell, Richard, William Pizer, and Daniel Raimi. 2013. "Carbon Markets 15 Years after Kyoto: Lessons Learned, New Challenges." Journal of Economic Perspectives 27(1): 123-146. doi: $\underline{10.1257 / j e p .27 .1 .123}$.

Pizer, William, and Andrew Yates. 2013. "Breaking Up May Not Be Hard to Do: Terminating Links between Emission Trading Programs." Working paper. www.hks.harvard.edu/var/ezp_site/storage/fckeditor/file/RPP_2013_12_Pizer_Yates(1).pdf.

Prometheum Carbon. 2013. "Carbon Pricing Scenarios." www.promethium.co.za/carbon/CARBON\%20PRICING\%20-\%20Promethuim\%20digital\%20lr.pdf.

Québec Ministère du Développement durable, de l'Environnement, de la Faune et des Parcs (Quebec MDDEFP). 2013. "The Québec Cap and Trade System for Greenhouse Gas Emissions Allowances: Regulatory Information." www.mddefp.gouv.qc.ca/changements/carbone/Systeme-plafonnementdroits-GES-en.htm, accessed August 3, 2013.

Ranson, Matthew, and Robert N. Stavins. 2013. "Post-Durban Climate Policy Architecture Based on Linkage of Cap-and-Trade Systems.” The Chicago Journal of International Law 13 (2): 403-438. http://search.proquest.com/docview/1290647348/13D59F9A202577E7152.

Regional Greenhouse Gas Initiative (RGGI). 2008. "Regional Greenhouse Gas Initiative Model Rule: 12/31/08 Final with Corrections. Part XX CO 2 Budget Trading Program." www.rggi.org/docs/Model\%20Rule\%20Revised\%2012.31.08.pdf

Regional Greenhouse Gas Initiative (RGGI). 2013a. "State Statutes \& Regulations.” http://rggi.org/design/regulations.

Regional Greenhouse Gas Initiative (RGGI). 2013b. "Summary of RGGI Model Rule changes, Feb. 2013." www.rggi.org/docs/ProgramReview/_FinalProgramReviewMaterials/Model_Rule_Summary.pdf

SendeCO ${ }_{2}$. 2013. " $\mathrm{CO}_{2}$ Prices: 2008-2013." www.sendeco2.com/uk/precio co2.asp?ssidi=3. Accessed September 2, 2013.

Shishlov, Igor, and Valentin Bellassen. 2012. Ten Lessons from Ten Years of the CDM. Climate Report 37. www.cdcclimat.com/IMG/pdf/12-10-05_climate_report_37__10_lessons_from_10_years_of_cdm.pdf

Sijm, J.P.M. 2009. "Tradeable Carbon Allowances: The Experience of the EU and Lessons Learned." Energy Research Centre of the Netherlands. www.ecn.nl/docs/library/report/2009/e09078.pdf, p. 21. 
Sopher, Peter and Mansell, Anthony. Norway - The World's Carbon Markets: A Case Study Guide to Emissions Trading." May 2013. www.edf.org/sites/default/files/EDF IETA Norway Case Study May 2013.pdf, pp. 1-2.

Sopher, Peter and Mansell, Anthony . Switzerland - The World's Carbon Markets: A Case Study Guide to Emissions Trading. May 2013. www.edf.org/sites/default/files/EDF_IETA_Switzerland_Case_Study_May_2013.pdf, pp. 1-2.

Tinbergen, Jan. 1962. Shaping the World Economy: Suggestions for an International Economic Policy. New York: Twentieth Century Fund.

Trotignon, Raphael. 2010. "Combining Cap-and-trade with Offsets: Lessons from CER Use in the EU ETS in 2008 and 2009." Climate Economics Chair of Paris-Dauphine University, Working Paper 2011-03. www.chaireeconomieduclimat.org/wp-content/uploads/2011/02/11-01-19-Trotignon-Useof-Offsets-in-the-EU-ETS-CEC1.pdf

United Nations Development Programme (UNDP). 2009. "The Clean Development Mechanism: An Assessment of Progress." http://assets.mediaglobal.org/documents/UNDP_Environment_and_Energy_Group_Report_The_Cle an_Development_Mechanism.pdf .

United Nations Environmental Program (UNEP), Risø Center. 2013. "CDM Pipeline Spreadsheet." http://cdmpipeline.org/ji-projects.htm. Accessed May 22, 2013.

United Nations Framework Convention on Climate Change (UNFCCC). 1998. Kyoto Protocol to the United Nations Framework Convention on Climate Change Article 3, par. 10. http://unfccc.int/resource/docs/convkp/kpeng.pdf.

United Nations Framework Convention on Climate Change (UNFCCC). 2012. "Benefits of the Clean Development Mechanism: 2012." http://cdm.unfccc.int/about/dev_ben/about/dev_ben/ABC_2012.pdf.

U.S. Energy Information Administration (EIA). 2011. Annual Energy Outlook 2011. DOE/EIA0383(2011). www.eia.gov/forecasts/archive/aeo11.

Wara, Michael. 2007. “Is the Global Carbon Market Working?” Nature 445: 595. doi:10.1038/445595a.

World Bank. 2013a. "GDP per Capita (current US\$)." http://data.worldbank.org/indicator/NY.GDP.PCAP.CD. Accessed September 13, 2013.

World Bank. 2013b. "Mapping Carbon Pricing Initiatives: Developments and Prospects, 2013." http://documents.worldbank.org/curated/en/2013/05/17751166/mapping-carbon-pricing-initiativesdevelopments-prospects. 